Article

\title{
Spatial and Temporal Characteristics of Snow Cover in the Tizinafu Watershed of the Western Kunlun Mountains
}

\author{
Jiangfeng She ${ }^{1}$, Yufang Zhang ${ }^{1}$, Xingong $\mathrm{Li}^{2,3, *}$ and Xuezhi Feng ${ }^{1}$ \\ 1 Department of Geographical Information Science, Nanjing University, Nanjing 210023, China; \\ E-Mails: gisjf@nju.edu.cn (J.S.); zhangyuf@whu.edu.cn (Y.Z.); xzf@nju.edu.cn (X.F.) \\ 2 Xinjiang Institute of Ecology and Geography, Chinese Academy of Sciences, \\ Wulumuqi 830011, China \\ 3 Department of Geography, University of Kansas, Lawrence, KS 66045, USA \\ * Author to whom correspondence should be addressed; E-Mail: lixi@ku.edu; \\ Tel.: +1-785-864-5545; Fax: +1-785-864-5378.
}

Academic Editors: Yuei-An Liou and Prasad S. Thenkabail

Received: 31 December 2014 / Accepted: 19 March 2015 / Published: 24 March 2015

\begin{abstract}
The Tizinafu watershed has a complex mountainous terrain in the western Kunlun Mountains; little study has been done on the spatial and temporal characteristics of snow cover in the region. Daily snow cover data of 10 hydrological years (October 2002 to September 2012) in the watershed were generated by combining MODIS Terra (MOD10A1) and Aqua (MYD10A1) snow cover products and employing a nine-day temporal filter for cloud reduction. The accuracy and window size of the temporal filter were assessed using a simulation approach. Spatial and temporal characteristics of snow cover in the watershed were then analyzed. Our results showed that snow generally starts melting in March and reaches the minimum in early August in the watershed. Snow cover percentages (SCPs) in all five elevation zones increase consistently with the rise of elevation. Slope doesn't play a major role in snow cover distribution when it exceeds $10^{\circ}$. The largest SCP difference is between the south and the other aspects and occurs between mid-October and mid-November with decreasing SCP, indicating direct solar radiation may cause the reduction of snow cover. While both the mean snow cover durations (SCDs) of the hydrological years and of the snowmelt seasons share a similar spatial pattern to the topography of the watershed, the coefficient of variation of the SCDs exhibits an opposite spatial distribution. There is a significant correlation between annual mean SCP and annual total stream flow, indicating that snowmelt is a major source of stream runoff that might be predictable with SCP.
\end{abstract}


Keywords: MODIS; snow cover percentage; snow cover duration; topography

\section{Introduction}

Snow cover plays an important role in the water budget of arid watersheds in western China and many other mountainous regions in the world. Globally, seasonal snow packs and glaciers in more than 50\% of mountain areas have an essential or supportive role for downstream water resources [1]. Snow cover is also an important indicator of local and global climate change. Many studies have documented recent declining and increasing trends of snow cover extent around the world in response to climate change [2-8]. The Tizinafu watershed, in regard to elevation, topography, and land cover, is a representative inland mountain watershed located in the western Kunlun Mountains. Snowmelt water from the mountain watershed is the primary water resource to support about 500,000 people who live in downstream oases. Because of the lack of precipitation in the desert climate in the region, irrigation agriculture in the oases is entirely dependent on the water from the mountain river. Characterizing the spatial distribution and temporal variation of snow cover in the Tizinafu watershed helps us to understand the hydrological processes and manage the water resources in the watershed.

Snow cover percentage (SCP) and snow cover duration (SCD) are the two most widely used snow cover parameters for snowmelt runoff modeling and water management in the watersheds dominated by melt water [9]. Traditionally, SCD is available at ground snow observation stations [2]. In large remote mountain watersheds, however, even those limited observations are usually scarce because of harsh environment and terrain accessibility. Remote sensing snow cover products, therefore, have been widely used to assess snow distributions in those regions. For instance, spatial variability of spring SCD over the Canadian Arctic was studied using a weekly National Oceanic and Atmospheric Administration (NOAA) snow cover dataset, a daily Interactive Multi-Sensor (IMS) snow cover product, passive microwave brightness temperatures, and scatterometer data [10]. Tong et al. [11] used the spatially-filtered Moderate Resolution Imaging Spectroradiometer (MODIS) snow cover products from 2000 to 2007 to assess the topographic control on SCP and SCD in the Quesnel River Basin of Canada. Qin et al. [12] studied the spatial and temporal variability of snow cover from 1951 to 1997 in western China, using Scanning Multichannel Microwave Radiometer (SMMR) snow-depth data, NOAA weekly snow extent products, and in situ snow observations. Based on multi-day combinations of Terra and Aqua MODIS snow cover products, Wang and Xie [13] examined the spatiotemporal variations of snow cover in northern Xinjiang, China, using three SCD maps and a snow cover index. Among remote sensing snow data and snow cover studies, MODIS snow cover products were frequently used due to their high temporal resolution (daily) and adequate spatial resolution for large mountain watersheds. While several studies have been carried out in western China [12-15], our research is different from previous studies in the region as we used high temporal resolution snow cover data with adequate spatial resolution and focused on an arid mountain watershed in the western Kunlun Mountains, which has a unique climate that is different from the other mountains in Xinjiang and western China. Compared with the work of Brown et al. [10], Qin et al. [12], and Wang and Xie [13], our research focused on examining the topographic controls on snow cover distribution in a smaller but more complex mountainous terrain 
in the northern slope of the Himalaya Mountains, where little study has been done. We also explored the relationship between snow cover percentage and stream flow, which has not been done by previous studies in the region [16].

The heterogeneous distribution of snow cover in mountain watersheds arises from the variability in meteorological (precipitation, temperature, radiation, and wind), topographical (elevation, slope, and aspect), and vegetative controls, among others $[11,17,18]$. The main goal of this study was to examine the spatial and temporal characteristics of snow cover in the arid mountain watershed of Tizinafu in the western Kunlun Mountains using MODIS daily snow products from October 2002 to September 2012. To this end, MODIS Terra and Aqua daily products were fused and a cloud removing method was assessed and then used to create a cloud-reduced data. This new daily snow cover data was then used to characterize the spatial and temporal distribution of snow cover and to study the effects of elevation, slope, and aspect on snow cover in the watershed.

\section{Study Area and Data}

\subsection{Study Area}

The Tizinafu watershed, which is located in the northern slope of the western Kunlun Mountains (Figure 1), covers an area of $5518 \mathrm{~km}^{2}$. Elevation ranges between 1575 and $6234 \mathrm{~m}$, increasing from north to south. Snow and glacier melt water accounts for most of the river flow that passes through downstream oases of the Yecheng, Zepu, Shache, and Markit counties. Land use in the downstream lowlands is mainly agricultural (cotton, wheat, and corn). The watershed sits at the southern edge of the Tarim River basin, with a typical arid continental climate of rare precipitation and strong evaporation. Average annual precipitation at the Jiangka hydro-climate station, located at the outlet of the Tizinafu watershed (Figure 1), is $120 \mathrm{~mm}$ and the mean minimum and maximum temperatures are $-12{ }^{\circ} \mathrm{C}$ and $29^{\circ} \mathrm{C}$, respectively [19].

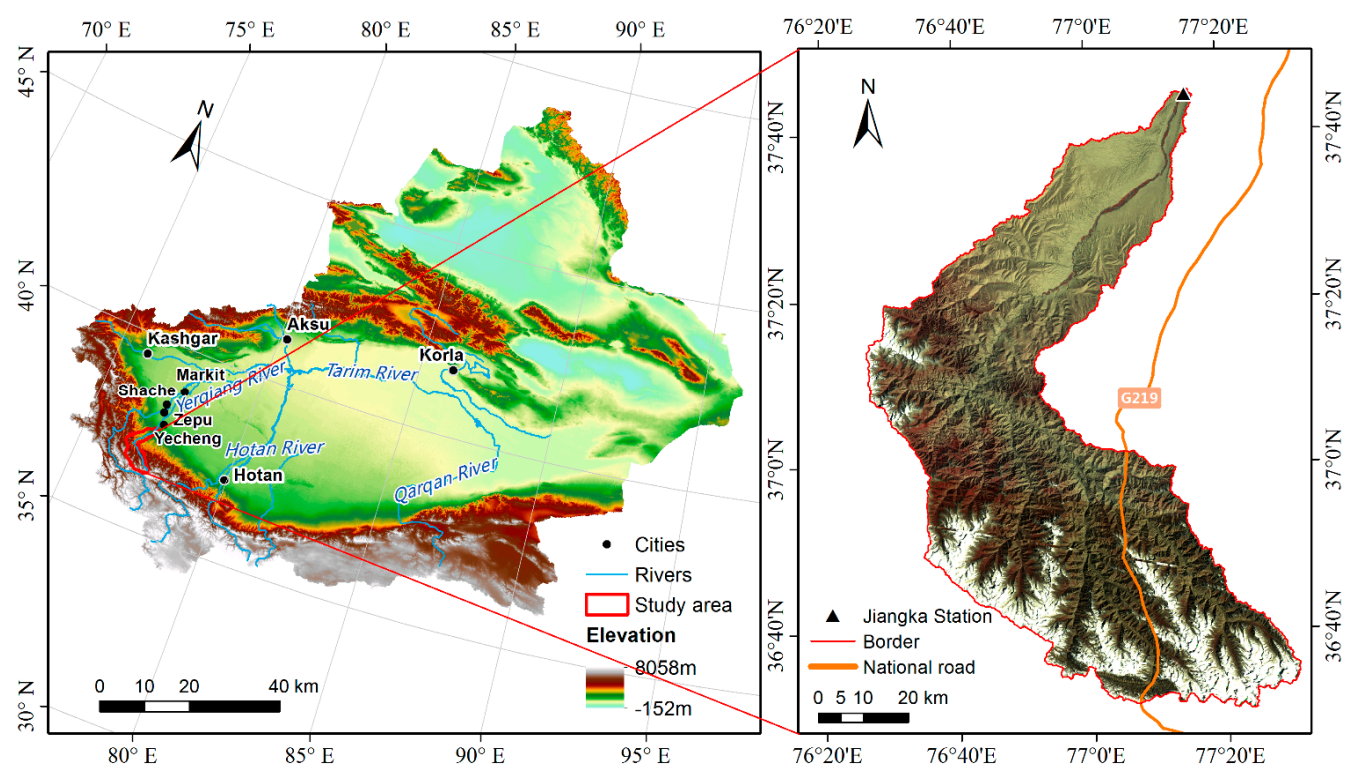

Figure 1. Location of the Tizinafu watershed in western China (left) and the Landsat TM image of 11 September 1976 showing snow cover within the watershed (right). 


\subsection{Data and Preprocessing}

MODIS is an imaging spectroradiometer mounted on the Terra and Aqua satellites of the National Aeronautics and Space Administration (NASA) Earth Observation System [20]. The Terra satellite started observation in February 2000 while the Aqua satellite began collecting data in July 2002. The differences in their orbits result in different viewing and cloud cover conditions. The most noticeable difference is the local equatorial crossing time: approximately 10:30 a.m. in a descending node for the Terra and approximately 1:30 p.m. in an ascending node for the Aqua satellite. MODIS provides imagery of the Earth's surface and clouds in 36 spectral bands from 0.4 to $14.4 \mu \mathrm{m}$. Based on snow's strong reflection in the visible bands and the strong absorption in the short-wave infrared bands, the SNOWMAP algorithm developed for MODIS allows the automatic generation of snow cover maps [21,22]. Daily, eight-day, and monthly global snow cover products are thus available through the Distributed Archive Center at the National Snow and Ice Data Center (NSIDC) [23].

The MODIS data used in this study include version 5 of the daily snow cover products MOD10A1 (Terra), MYD10A1 (Aqua), and eight-day maximum snow cover product MOD10A2 (Terra) at the spatial resolution of $500 \mathrm{~m}$, covering 10 hydrological years from October 2002 to September 2012. MODIS tile $\mathrm{h} 24 \mathrm{v} 05$ covers the entire watershed. The tile data was first downloaded and then reprojected to the Albers equal area conic projection using the MODIS Reprojection Tool [24]. After the transformation, the MODIS snow cover products were reclassified from 11 classes [25] to four categories (Table 1). The reclassified data were further processed to remove cloud coverage before analyses.

Table 1. Reclassification of MODIS snow cover products.

\begin{tabular}{cccc}
\hline & MODIS Snow Cover Classes & \multicolumn{2}{c}{ Reclassified Classes } \\
\hline Value & Description & Value & Description \\
0 & data missing & 19 & missing \\
1 & no decision & 19 & missing \\
11 & night & 19 & missing \\
25 & no snow & 101 & snow-free \\
37 & lake & 101 & snow-free \\
39 & ocean & 101 & snow-free \\
50 & cloud & 50 & sloud \\
100 & lake ice & 200 & snow \\
200 & snow & 200 & missing \\
254 & detector saturated & 19 & missing
\end{tabular}

The original digital elevation model (DEM) used in this study is the 30-meter resolution Advanced Spaceborne Thermal Emission and Reflection Radiometer (ASTER) GDEM version 2 (Ministry of Economy, Trade, and Industry and NASA) [26]. The DEM was resampled to $500 \mathrm{~m}$, using a bilinear resampling method, to match with the resolution of the MODIS snow cover data. Slope and aspect were then calculated from the DEM. Figure 2 shows the hypsometric curve, slope band percentages, and aspect rose diagram of the watershed. 


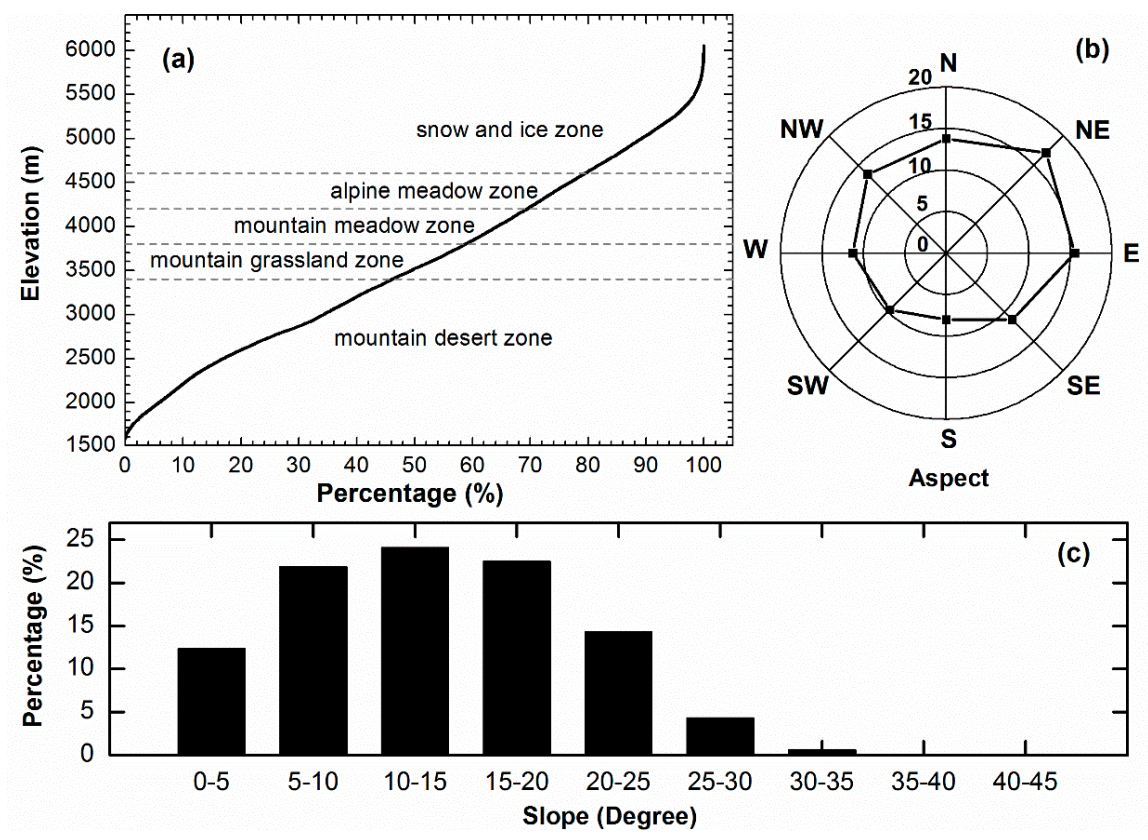

Figure 2. (a) Hypsometric curve, (b) area percentages of slope bands, and (c) aspect rose diagram of the Tizinafu watershed.

\section{Methods}

\subsection{Cloud Gap Filling Methods}

Hall et al. [27] concluded that under clear sky conditions, the overall accuracy of MODIS daily snow cover products is about 93\%. Numerous applications of MODIS daily snow cover products have demonstrated their high accuracy and good agreement with satellite and ground snow observations [28-30]. However, in many regions, especially in the alpine mountains in western China, persistent cloud cover is a serious obstacle to the application of MODIS snow cover products.

Wang et al. [31] and Xie et al. [32] evaluated the combination of MODIS Terra and Aqua snow cover products using in situ snow data and indicated that the combination improved snow cover accuracy against either Terra or Aqua (51\% against 44\% and 34\% for daily, and $92 \%$ against $77 \%$ and $78 \%$ for eight-day snow cover data). Gao et al. $[33,34]$ also showed that the combination of Terra and Aqua data could reduce cloud cover by about 10\%. Using the information from neighboring non-cloud covered pixels in time and space, Parajka and Blöschl [35] developed various spatial and temporal filters to remove cloud. Using snow observations at 754 climate stations, they evaluated the accuracy of their cloud reduction methods and found that the filtering techniques are remarkably efficient in cloud reduction and the resulting snow maps are in good agreement with ground snow observations. Specifically, the seven-day temporal filter reduced cloud coverage from $63 \%$ to $4 \%$ but still maintained an overall snow accuracy of $92.1 \%$. Gafurov and Bardossy [36] used a similar approach that consists of six successive steps to fill cloud gaps using different temporal and spatial information. Since no ground observations were available, they used simulated data to test their methodology. Parajka et al. [37] also proposed and evaluated another cloud reduction method based on regional snow-line elevation. However, the best cloud coverage reduction by the method is $10.4 \%$ with an overall snow accuracy of $91.5 \%$, which is not as good as the simpler temporal filtering method. Hall et al. [38] also used a temporal 
filter technique (called cloud-gap-filled) similar to Parajka and Blöschl's [35] to reduce cloud coverage and assessed the method using assimilation experiments with a land surface model. Their results indicated a domain-averaged bias improvement of $12 \%$ from the model using a five-day temporal filter. Using in situ data, Gao et al. [39] further revealed the cloud-gap-filled technique increased Terra snow cover accuracy from $25.4 \%$ to $56.8 \%$ and $66.6 \%$, respectively, using prior and subsequent clear observations within a five-day window. Dozier et al. [40] developed the MODSCAG algorithm [41], retrieving fractional snow cover and grain size from MODIS data. They interpolated missing fractional snow cover using a piecewise interpolant after first applying smoothing splines. The accuracy of their methods, however, was not validated with ground observations. In summary, those studies indicated that the combination of Terra and Aqua products and the use of a temporal filter are valid and practical methods of reducing clouds in MODIS snow cover products.

We firstly reclassified MODIS Terra MOD10A1 and Aqua MYD10A1 classes into four general categories (snow, snow-free, cloud, and missing in Table 1). When combining the reclassified datasets, a cell would be categorized as snow when it is snow on either Terra or Aqua image and as cloud only when it is cloud on both Terra and Aqua images. Except for snow, Terra classes were used as the primary data source whenever there was inconsistency between Terra and Aqua classes. To further reduce cloud obstruction, the combined data (MODMYD10A1) were then processed by assigning a cell, in the case of cloud cover, the category of the most recent clear observation within a temporal window, assuming that ground cover changes are not very marked within the temporal window [35]. In a case where the most recent clear observation occurs both at a prior and subsequent day, the category of the previous day was used to replace the cloud. The accuracy of the temporal filter and window size was first assessed and the filtered data was then used in subsequent analyses.

\subsection{Snow Cover Percentage (SCP) and Snow Cover Duration (SCD)}

SCP and SCD are two widely used parameters characterizing the spatial and temporal distribution of snow cover. Both parameters are affected by topographical controls such as elevation, slope, and aspect. Spatial and temporal variations of SCP and SCD, combined with the effects of elevation, slope, and aspect, were analyzed for the watershed. Based on the altitudinal belts of the western Kunlun Mountains [42], the watershed was divided into five elevation zones: mountain desert zone $(<3400 \mathrm{~m})$, mountain grassland zone (3400-3800 m), mountain meadow zone (3800-4200 m), alpine meadow zone $(4200-4600 \mathrm{~m})$, and snow and ice zone $(>4600 \mathrm{~m})$. The watershed was also divided into five slope groups $\left(<10^{\circ}, 10-15^{\circ}, 15-20^{\circ}, 20-25^{\circ}\right.$, and $\left.>25^{\circ}\right)$ and four aspect directions (north $\left(0-45^{\circ}\right.$ and $\left.315-360^{\circ}\right)$, east $\left(45-135^{\circ}\right)$, south $\left(135-225^{\circ}\right)$, and west $\left(225-315^{\circ}\right)$ ) to study the effects of slope and aspect on snow cover distribution.

Daily SCP, defined here as the percent snow cover within the whole watershed, is calculated as the ratio between the number of pixels in the watershed covered by snow and that not obstructed by clouds. This gives the best SCP estimate when clouds occur randomly within a watershed. Accordingly, SCP for a given elevation band is defined as the ratio between the number of snow-covered pixels and the number of cloud-free pixels within the band. Daily SCPs in the 10 hydrological years were calculated for the above elevation, slope, and aspect zones using the MODMYD10A1 snow cover data. In addition, 
SCPs in snowmelt season (March to August) were also calculated with finer elevation (200-m), slope $\left(2^{\circ}\right)$, and aspect $\left(45^{\circ}\right)$ zones.

$\mathrm{SCD}$ is defined as the number of days with snow cover on the ground in a certain time period. The mean, standard deviation, and coefficient of variation (CV) of SCD in hydrological years and snowmelt season (between March and August) were firstly calculated. Then, SCDs for each $200 \mathrm{~m}$ elevation band in the snow melting period were obtained. Finally, the mean, standard deviations, and CV of annual SCD for every 20 m elevation band were computed by averaging the SCD statistics of all pixels in the given $20 \mathrm{~m}$ elevation bands.

\section{Assessment on the Temporal Filter}

Our literature review indicated that, after combining the Terra and Aqua products, the temporal filter that uses the most recent clear observation to reduce cloud is the most effective cloud-gap-filling method for the MODIS snow products. Many previous assessments of cloud-gap-filling methods used weather station snow observations as ground truth. One serious limitation of field snow data is its incompatible spatial resolution with MODIS pixel size, which is about $500 \mathrm{~m} \times 500 \mathrm{~m}$.

In this research we used synthetic snow cover time series data to assess the accuracy of the temporal filter and the cutoff of the window size. Cloud-free snow cover maps observed from MODIS were used as the "ground truth" and cloud cover maps from MODIS were added to generate daily snow cover time series. Since snow cover is dynamic and its distribution is most valuable in snow melt season, we used snow and cloud cover maps between April and August for the assessment. We found 88 cloud-free days in the watershed during the 10 snowmelt seasons. Snow cover percentages on those days varied between $3.9 \%$ and $49.9 \%$, with a mean of $16.9 \%$. We sorted (in descending order) the snow cover percentages associated with daily snow cover maps and arranged the maps based on the sorted snow cover percentages to create a mono-decreasing daily snow cover time series of 88 days. This data was used as the "ground truth" snow cover maps. We then randomly selected 88 days of continuous cloud cover maps from MODIS during the snowmelt seasons. We inserted cloud to the snow cover maps by replacing the pixels on the snow cover maps with the cloud from the cloud cover maps. Through this approach, we generated 100 sets of synthetic daily snow cover time series data of 88 days long. Each of the synthetic snow cover time series was created using the same "ground truth" snow cover maps but with different cloud cover maps. We assessed the accuracy of the temporal filter with different temporal window sizes. Figure 3 shows that mean absolute errors of snow cover percentage dropped significantly from $53 \%$ when not using the temporal filter (i.e., window size $=1$ ) to $3.5 \%$ when using a temporal window of nine days, and larger window sizes did not improve the accuracy. Based on this assessment, a nine-day (four prior and four subsequent days) temporal filter was used to reduce cloud cover for subsequent analyses. 


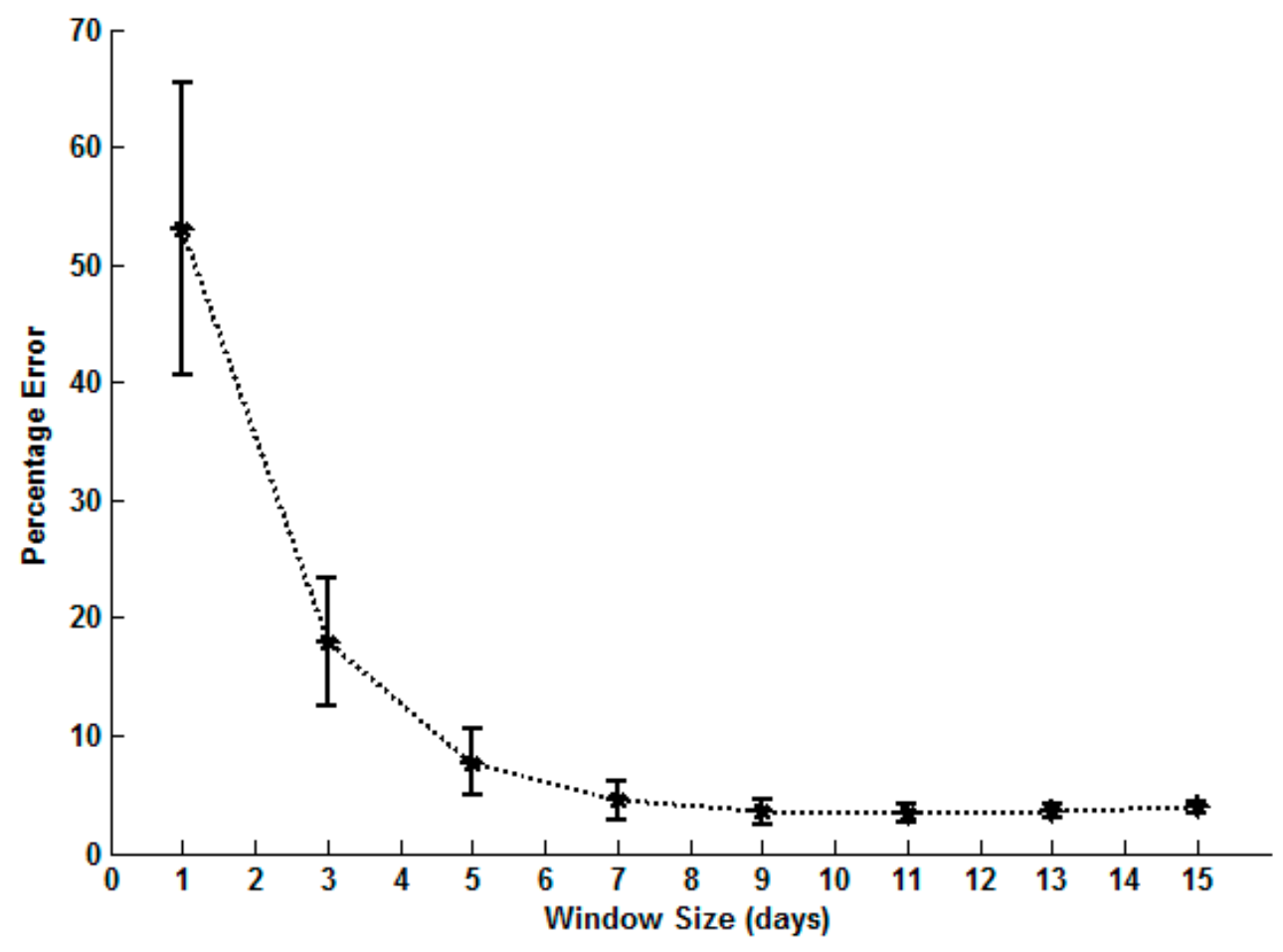

Figure 3. Mean absolute errors of snow cover percentage using a temporal filter with different window sizes. Vertical bars indicate the one standard deviation of the absolute errors with different window sizes.

\section{Spatial and Temporal Characteristics of Snow Cover}

\subsection{Spatial and Temporal Variation of SCP}

Figure $4 \mathrm{a}$ shows the mean daily SCP of the 10 hydrological years in the watershed and five elevation zones. There is an obvious annual pattern where snow generally starts melting from March and reduces to the minimum in early August. Melting dates in low elevation zones start earlier than those in high elevation zones. Then, snow begins accumulating until it reaches the maximum in mid-October. Average daily SCP (black line in Figure $4 \mathrm{a}$ ) in the watershed ranges from 5.5\% to 42.2\%. There is a persistent decrease of SCP between mid-October and December, which is probably due to snowmelt caused by direct solar irradiance and the lack of moisture (except for a few snow events) supply in those months.

The effect of elevation on SCP is obvious, as manifested by the SCPs in the five elevation zones, which increase consistently with elevation. Furthermore, the snow and ice zone (>4600 m) was divided into two groups, i.e., the above $5000 \mathrm{~m}$ group and the 4600-5000 m group. The area percentages of those six elevation zones (i.e., $<3400 \mathrm{~m}, 3400-3800 \mathrm{~m}, 3800-4200 \mathrm{~m}, 4200-4600 \mathrm{~m}, 4600-5000 \mathrm{~m}$, and $>5000 \mathrm{~m}$ ), are $45.8 \%, 12.7 \%, 10.8 \%, 9.9 \%, 9.8 \%$, and $11.0 \%$, respectively. As shown in Figure $4 \mathrm{a}$, the above $5000 \mathrm{~m}$ group has a maximum SCP of $96.8 \%$ in March and is almost always above $50 \%$, probably due to the presence of perennial snow or ice cover in the group. The SCPs for the $4600-5000 \mathrm{~m}$ group range from $5.3 \%$ to $83.0 \%$, showing a larger annual fluctuation than the above 5000 $\mathrm{m}$ group. The other four elevation zones share a similar annual pattern with the average SCP of the watershed, which rarely exceeds 50\% and gradually reaches zero between July and August. 


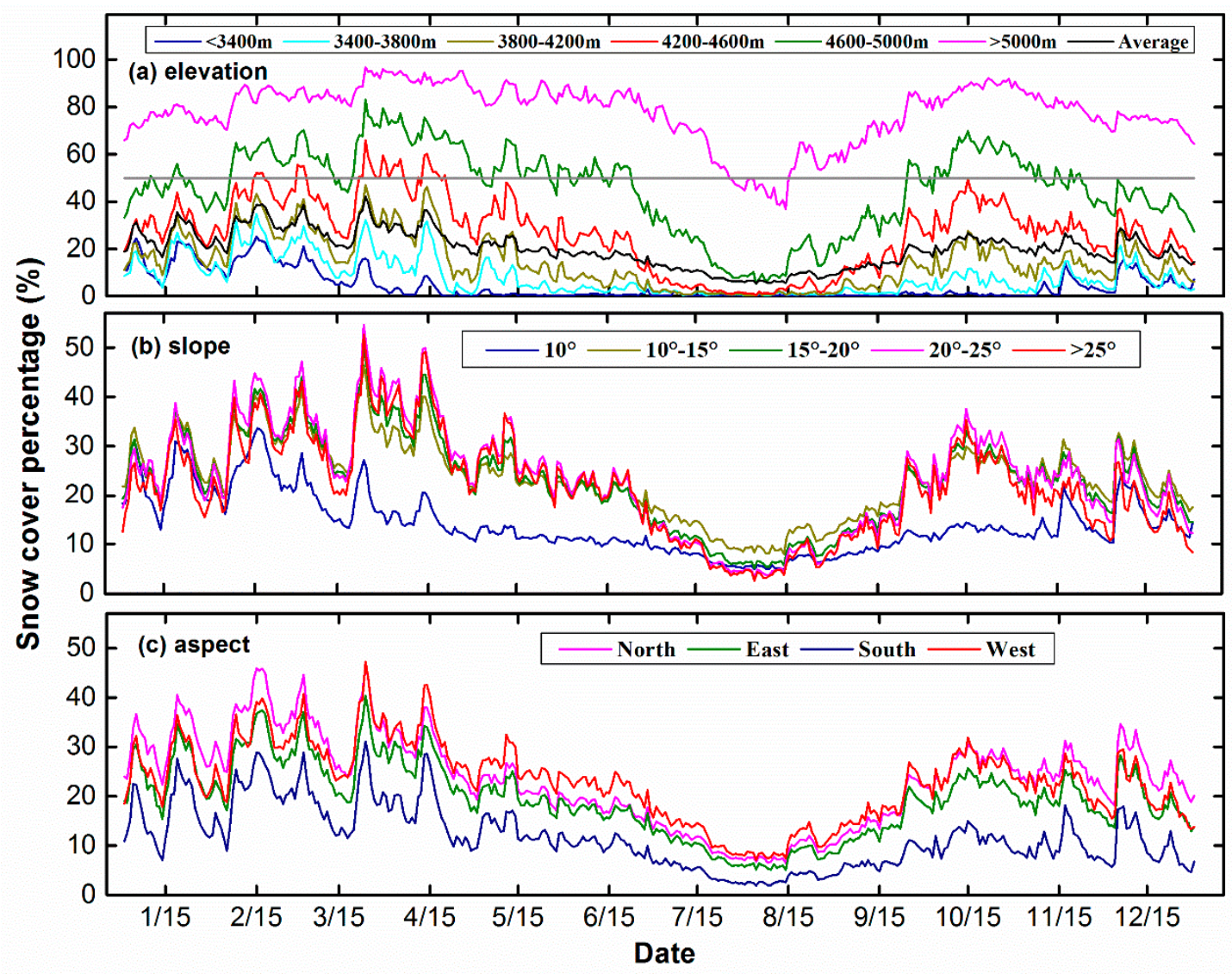

Figure 4. Mean daily SCP in (a) elevation, (b) slope, and (c) aspect zones during 10 hydrological years from October 2002 to September 2012. The gray solid line in (a) denotes a SCP of $50 \%$.

Snow cover in the watershed is also affected by slope and aspect through local solar radiation and moisture conditions. Figure $4 \mathrm{~b}$ shows the mean daily SCP distribution in five slope bands. The area percentages of the five slope bands $\left(<10^{\circ}, 10-15^{\circ}, 15-20^{\circ}, 20-25^{\circ}\right.$, and $\left.>25^{\circ}\right)$, are $34.2 \%, 24.1 \%, 22.5 \%$, $14.3 \%$, and $4.9 \%$, respectively. In the area with slope less than $10^{\circ}$, SCPs are the lowest as well as the annual fluctuation of SCPs, ranging from $4.7 \%$ to $33.7 \%$. This slope band accounts for $34.2 \%$ of the watershed and is mostly downstream low elevation areas. Since slope and elevation are correlated to some extent, this is likely the reason why this slope band has the lowest SCP. For the other four slope bands, their daily SCP curves are basically identical, with SCP ranging from near 5\% to near 50\%. Slope appears to be less important than elevation in determining SCP.

The effect of aspect is shown in Figure 4c. The area percentages of the four aspect zones (North, East, South, and West), are 29.2\%, 30.8\%, 17.2\%, and 22.8\%, respectively. Since the watershed is located in the northern slope of the western Kunlun Mountains, the south aspect accounts for the smallest area in the watershed. The SCPs of the south group, as well as its annual fluctuation, which ranges from 1.8\% to $31.1 \%$, are the lowest among the aspect bands. This is due to the fact that south-facing aspects receive more solar radiation, which often enhances snowmelt between storms, resulting in less accumulation on these aspects over the course of the year. The daily SCP curves of the other three aspect groups are similar, with SCPs ranging from 5\% to $47.3 \%$. The largest difference between the south and the other aspect groups occurs between mid-October and mid-November with decreasing SCP. Several 
temperature-index based snowmelt runoff modeling studies have included the effect of solar radiation on snow melt and there is a strong theoretical basis that direct solar radiation may cause the reduction of snow cover $[19,43,44]$.

The effect of elevation on SCP during the snowmelt season (from March to July) is shown in Figure 5a. Snow starts melting earlier at low elevations and snowmelt in different months occurred in different elevation bands. SCPs at all elevations show a decreasing trend from April to July. By July, SCPs at the elevation below $4000 \mathrm{~m}$ reduce to zero. The largest decrease in SCP occurred between June and July in the elevation band between 5000 and $5200 \mathrm{~m}$. The SCPs between $10 \%$ and $80 \%$ exhibit a strong linear relationship with elevation, with increasing slopes of $5.1 \%(200 \mathrm{~m})^{-1}, 10.0 \%(200 \mathrm{~m})^{-1}, 10.5 \%(200 \mathrm{~m})^{-1}$, $14.6 \%(200 \mathrm{~m})^{-1}$, and $18.1 \%(200 \mathrm{~m})^{-1}$ for the months from March to July, respectively.

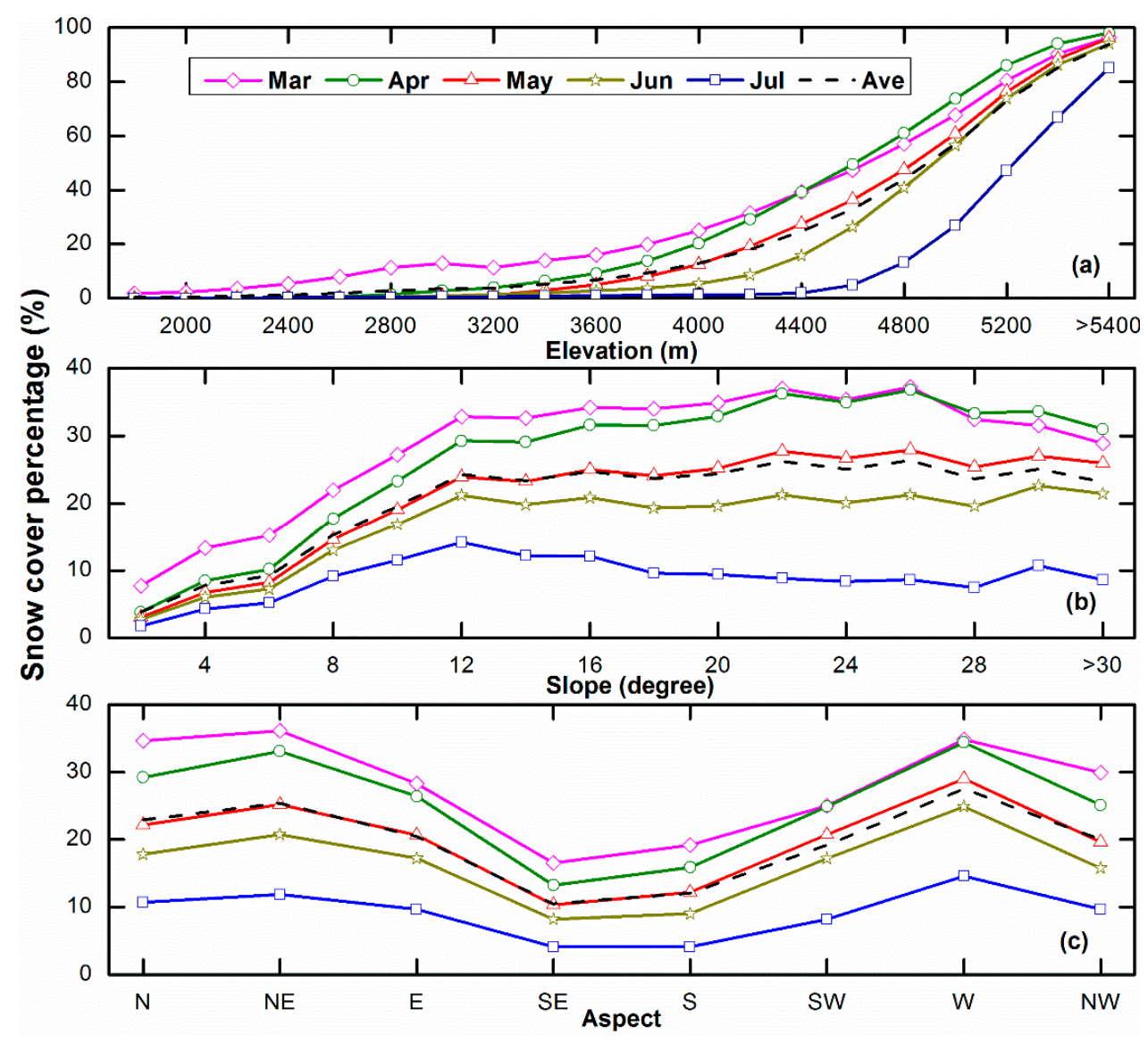

Figure 5. Mean SCPs in snowmelt season (March to July) of hydrological years from October 2002 to September 2012 and in different (a) elevation, (b) slope, and (c) aspect bands.

The effects of slope and aspect on SCP during snowmelt season (March to July) are shown in Figures $4 \mathrm{c}$ and $5 \mathrm{~b}$. SCP in all slope and aspect groups shows a decreasing trend from April to July, with the largest reduction from June to July. SCP increases with slopes less than $12^{\circ}$, and then stays relatively level. This indicates that slope does not influence SCP beyond $12^{\circ}$. The south and southeast aspects have the lowest SCPs while the northeast and west aspects have the highest SCPs for each month. The biggest SCP difference among the aspect groups is $21.1 \%$, which occurs in April between the west and southeast aspect groups. 


\subsection{Spatial and Temporal Variations of SCD}

SCD is also a sensitive indicator of change that has been widely used in snow cover studies [10,45-47]. Figure 6 shows the mean, standard deviation, and CV of SCD within a hydrological year and within the snowmelt season during the 10 hydrological years. The mean SCD in a hydrological year and in the snowmelt season (Figure 6a,d) share a similar spatial pattern to the DEM of the watershed. Areas with large SCDs are mostly located in the southern, high-elevation part of the watershed, reaching up to over 300 days in a hydrological year and 135 days in the snowmelt season. Areas in the northern, low-elevation part of the watershed have SCDs less than 30 days in a hydrological year and 15 days in the snowmelt season.
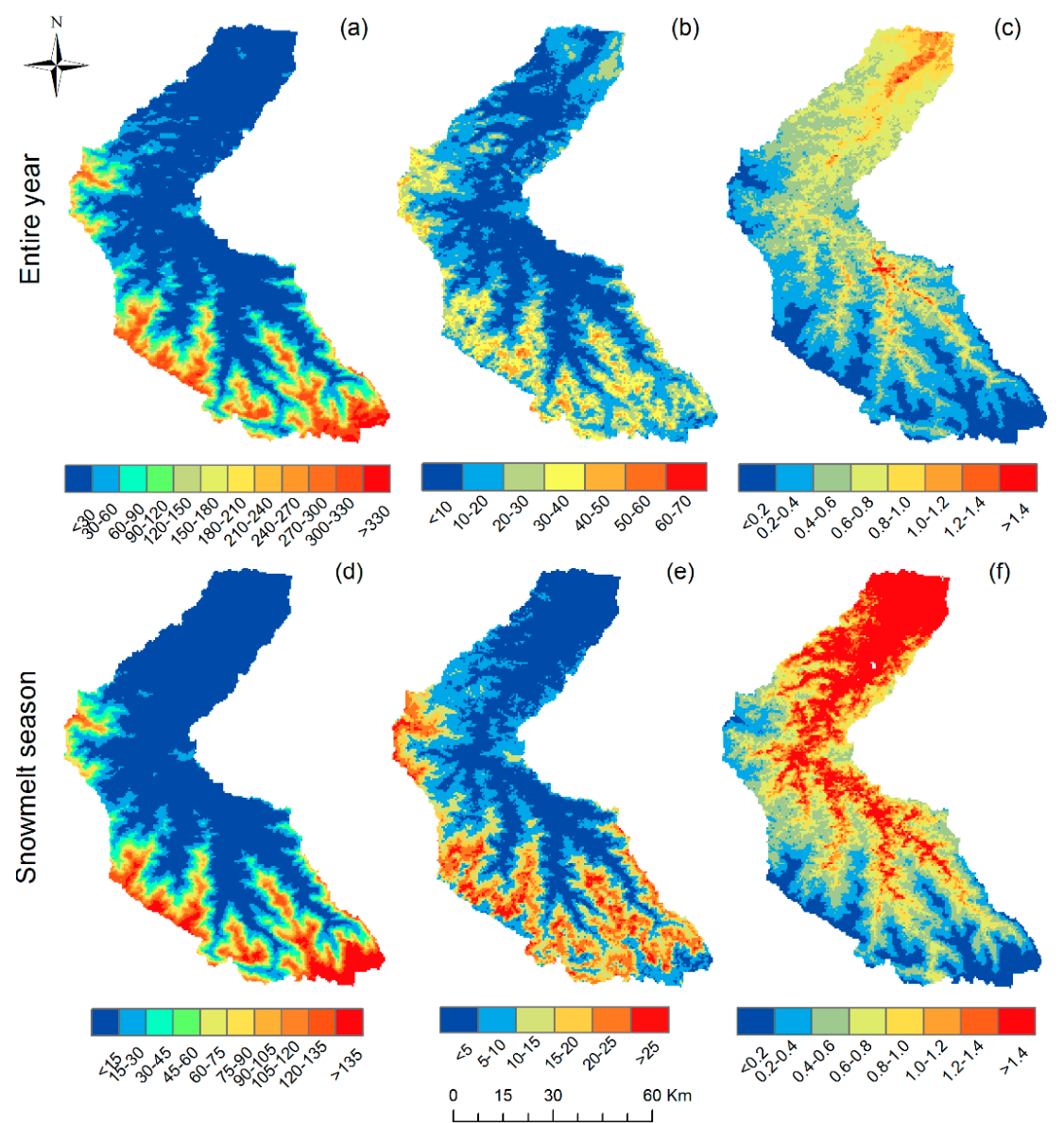

Figure 6. Spatial distributions of the (a) mean, (b) standard deviation, and (c) CV of SCD in a hydrological year, and the (d) mean, (e) standard deviation, and (f) CV of SCD in snowmelt season for 10 hydrological years from October 2002 to September 2012.

The standard deviations of SCD in the hydrological years and in the snowmelt season (Figure 6b,e) show that the variation of SCD occurred in the narrow bands next to the areas of the highest SCD, with a maximum of about 70 days in a hydrological year and 25 days in the snowmelt season. Considering that the standard deviation is less than 30 days in a hydrological year and 15 days in the snowmelt season in most areas, the inter-annual variation of SCD is generally minor.

The CVs of SCD (Figure 6c,f) exhibits an opposite spatial pattern compared to the distribution of mean SCDs (Figure 6a,d) in both hydrological year and snowmelt season. Areas with high mean SCD 
show low CV. For instance, areas with mean SCD over 300 days have CVs less than 0.2. Due to low temperature and abundant precipitation on windward slopes, SCD in high elevation areas is larger and more stable than that in low elevation areas. The CVs in the areas with mean annual SCD less than 30 days exceed 1.0. With warm temperatures and rare precipitation, snow cover in those low elevation areas is more vulnerable to the local meteorological factors. Compared with annual SCD, snowmelt season SCD has more areas with CVs exceed 1.0, which may be due to the sharper variation of snow cover during the snowmelt season.

The effect of elevation on SCD during the snowmelt season (March to July) is shown in Figure 7, which is similar to Figure 5a. The largest decrease in SCD occurred between June and July at the elevation band between 5000 and $5200 \mathrm{~m}$. For SCDs between 5 and 20 days, they exhibit a strong linear relationship with elevation in all months, with increasing slopes $(\mathrm{d}(\mathrm{SCD}) / \mathrm{dz})$ of 2.3 days $(200 \mathrm{~m})^{-1}$, 3.0 days $(200 \mathrm{~m})^{-1}, 3.0$ days $(200 \mathrm{~m})^{-1}, 4.4$ days $(200 \mathrm{~m})^{-1}$, and 5.9 days $(200 \mathrm{~m})^{-1}$ from March to July, respectively.

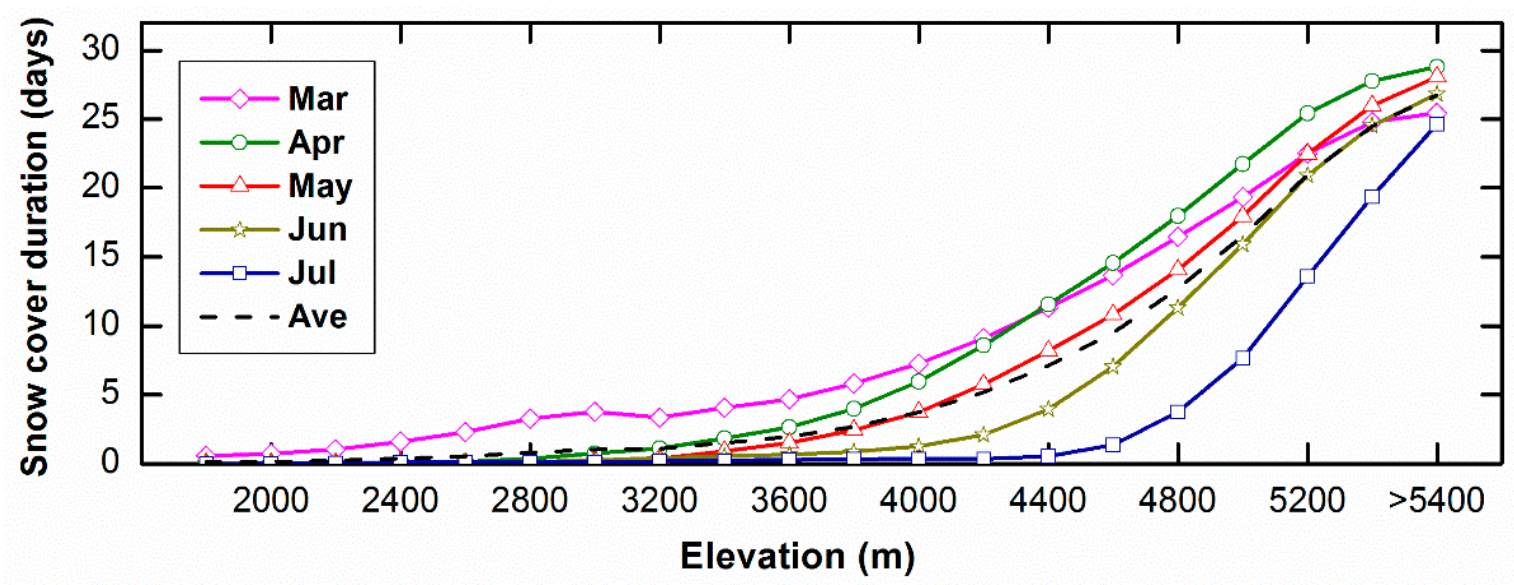

Figure 7. Mean SCDs for the months during snowmelt season (March to July) in $200 \mathrm{~m}$ elevation bands.

Topographical control on SCD is illustrated in Figure 8. The mean, standard deviation, and CV of annual SCD for each 20-m elevation band were calculated. The mean SCD curve exhibits an S-shape curve. The mean SCD of the 10 hydrological years ranges from 11 to 340 days, and areas with SCD less than 60 days are all below $4000 \mathrm{~m}$. For elevation above $4000 \mathrm{~m}$, mean SCD rises rapidly with elevation until it reaches a plateau of above 300 days. Standard deviation increases slowly with elevation until it reaches the maximum of 71 days at about $4800 \mathrm{~m}$. It then decreases with elevation and reaches zero at about $6000 \mathrm{~m}$ due to the existence of perennial snow or ice cover. CV first fluctuates with elevation below $2250 \mathrm{~m}$. It increases with elevation, reaches a maximum of 0.85 at about $3000 \mathrm{~m}$, and then decreases to zero. 


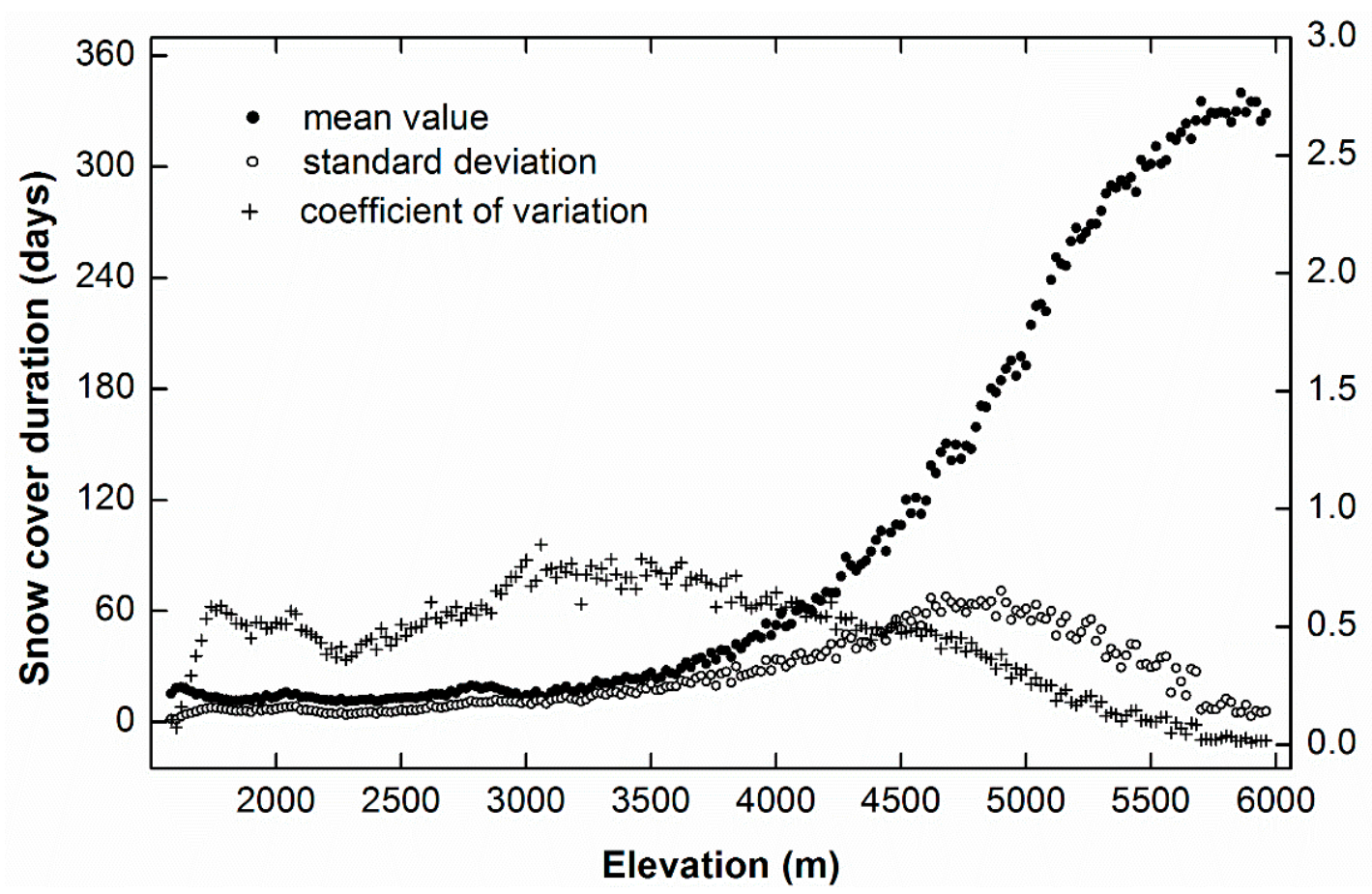

Figure 8. Variation of the mean (black dots), standard deviation (white dots), and CV (plus signs) of annual SCD with elevation.

\subsection{Relationship between Snow Cover Percentage and Stream Flow}

Annual mean SCPs and total stream flow (at the Jiangka station in Figure 1) of the 10 hydrological years are shown in Figure 9. Hydrological years 2007and 2009 had the lowest annual mean SCPs as well as the lowest annual total stream flow at the watershed outlet. Hydrological years 2005, 2010, and 2012 had the highest annual mean SCPs and so did their annual total stream flow. There is a significant correlation between SCP and stream flow $(\mathrm{r}=0.78$ and $p=0.007)$, indicating the predictability of stream flow using SCP. If the data from 2007 are excluded, the correlation between SCP and stream flow is much higher $(\mathrm{r}=0.95$ and $p=0.000)$. The year 2007 had the lowest SCP but not the least stream flow. Considering the high SCP in the previous year (i.e., 2006), this implies that other sources, such as groundwater, may also play an important role, especially in dry years. This may also explain why the year 2011 had a relatively low SCP but still had a relatively high stream flow. Our recent hydrograph isotope analysis [48] indicated that, at annual scale, $41 \%$ of stream flow is from groundwater, although rainfall and melt water contribute $59 \%$ of the stream flow.

We further examined the relationship between annual stream flow and the SCPs in five different elevation bands. The results (Table 2) indicated that snow cover in the three elevation bands between 3400-5000 $\mathrm{m}$ has a significant and stronger correlation with annual stream flow than the SCP of the watershed has. While the SCP in the 4200-4600 m elevation band has the strongest correlation, the SCPs in the lowest and highest elevation bands do not have significant correlation with annual stream flow.

Table 2. Correlation between annual stream flow and the SCPs in different elevation bands.

\begin{tabular}{ccccccccc}
\hline & $<\mathbf{3 4 0 0} \mathbf{~}$ & $\mathbf{3 4 0 0}-\mathbf{3 8 0 0} \mathbf{~}$ & $\mathbf{3 8 0 0}-\mathbf{4 2 0 0} \mathbf{~ m}$ & $\mathbf{4 2 0 0}-\mathbf{4 6 0 0} \mathbf{~ m}$ & $\mathbf{4 6 0 0}-\mathbf{5 0 0 0} \mathbf{~ m}$ & $\mathbf{> 5 0 0 0} \mathbf{m}$ & Watershed \\
\hline $\mathrm{r}$ & 0.60 & 0.76 & 0.79 & 0.82 & 0.79 & 0.51 & 0.78 \\
$p$ & 0.069 & 0.010 & 0.006 & 0.003 & 0.006 & 0.128 & 0.007 \\
\hline
\end{tabular}




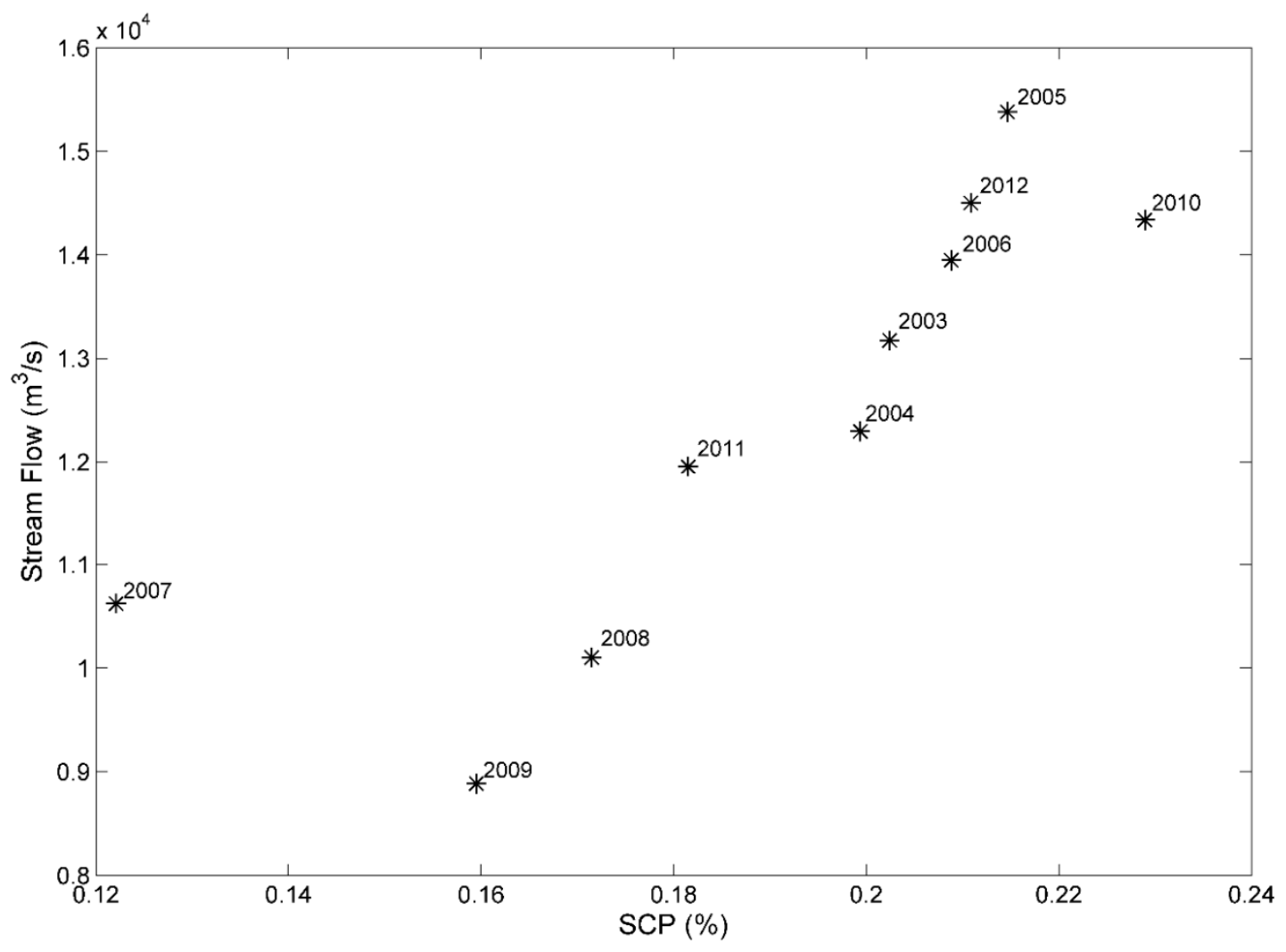

Figure 9. Annual mean SCPs and total stream flow in the 10 hydrological years in the Tizinafu watershed.

\section{Discussion}

Clouds are the main factor limiting the applications of MODIS snow cover products, especially in the mountainous areas of western China. We combined daily MODIS Terra and Aqua snow-cover products and then applied a nine-day temporal filter to further reduce the cloud coverage in the combined data. The accuracy of our snow cover data, however, is hard to evaluate as ground observation stations in the region are few and generally located at low elevations. Landsat images have a higher resolution than MODIS but they are likely obstructed by the same clouds as MODIS and may not be used to evaluate the cloud-gap-filling methods.

Using a simulation approach, we assessed the accuracy of the temporal filter, which has the lowest mean absolute error of $3.5 \%$ with a nine-day window size. MODIS eight-day maximum snow cover product MOD10A2 also uses a temporal filter and reduces cloud coverage by $36.7 \%$ on average in the Tizinafu watershed, with the maximum cloud cover reduction from $80 \%$ to $20 \%$ (Figure 10 ). However, the temporal resolution is decreased from daily to eight days. Compared to the MOD10A2 product, our cloud-gap-filled daily snow cover data further reduced cloud coverage in February and July but still reserved its daily temporal resolution.

There is an obvious annual pattern where snow generally starts melting from March and reduces to the minimum in early August. From September, snow then begins accumulating until the maximum coverage in mid-October. The elevation control of SCP is obvious, manifested by the consistent increase of SCP with the rising of elevation in the five elevation zones. In the areas with slope lower than $10^{\circ}$, 
SCPs are the lowest as well as the annual variation of SCPs. For the other four slope groups, their daily SCP curves are basically identical, with SCPs ranging from nearly 5\% to 50\%. The south-facing aspects ( $\mathrm{S}, \mathrm{SE}$, and $\mathrm{SW}$ ) have the lowest SCPs compared to other aspects, probably due to the fact that south-facing areas receive more direct solar radiation and thus have less snow cover.

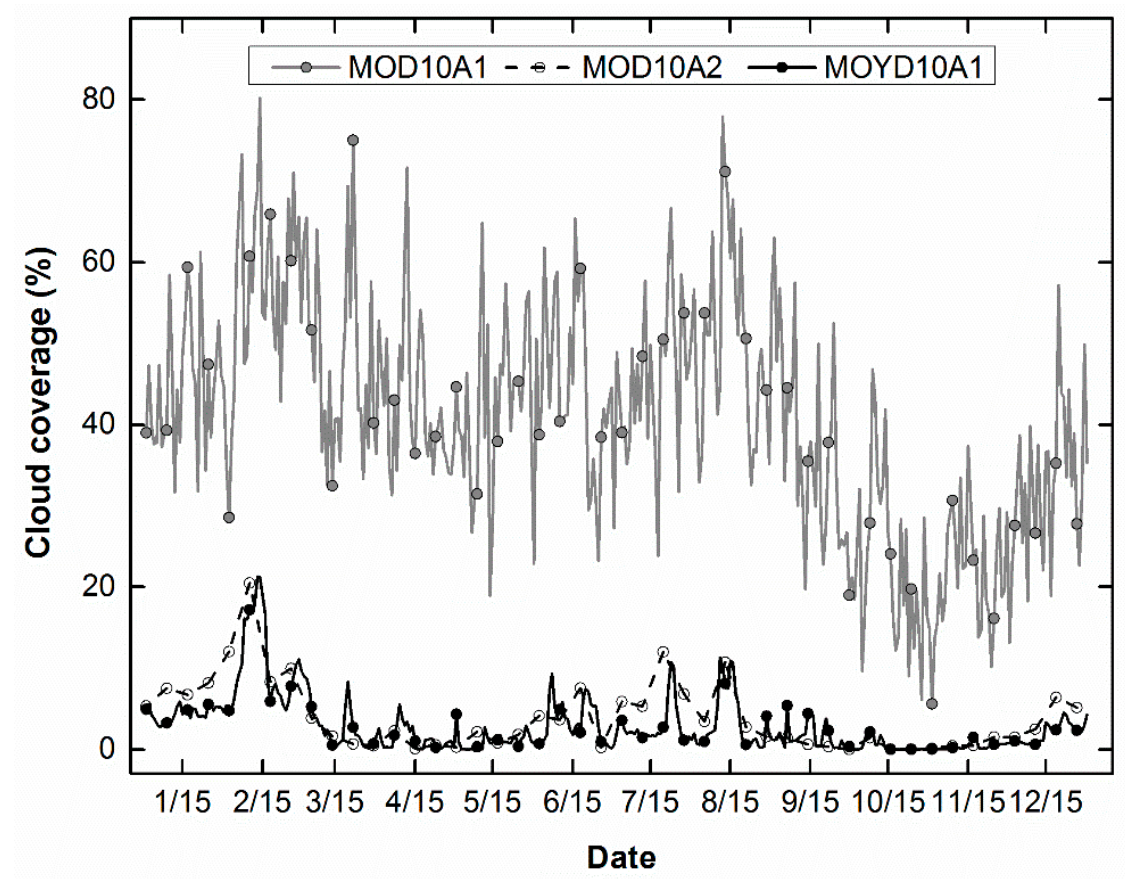

Figure 10. Average daily cloud cover percentages of three snow cover data: MODIS Terra daily snow cover (MOD10A1), MODIS Terra eight-day maximum snow cover (MOD10A2), and our cloud-gap-filled daily snow cover (MODMYD10A1) from October 2002 to September 2012.

The effect of elevation during the snowmelt season is clearly shown for the SCPs between $10 \%$ and 80\%: All of the SCP depletion curves exhibit a linear relationship with elevation, with a rate of change ranging from $5.1 \%(200 \mathrm{~m})^{-1}$ to $18.1 \%(200 \mathrm{~m})^{-1}$ from March to July. Different from elevation, SCPs exhibit non-linear relationships with slope and aspect.

Mean annual and snowmelt season SCDs share a similar spatial pattern with the topography of the watershed. Areas with large SCD are located in the southern, high-elevation part of the watershed, while areas in the northern, low-elevation part of the watershed have the lowest SCD. The standard deviations of annual and snowmelt season SCDs show that the variations occur in the narrow band next to the areas with the highest SCD. The CV of the annual and snowmelt season SCDs exhibited a spatial pattern opposite to that of the mean SCD. The effect of elevation on SCD is similar to that on SCP during the snowmelt season. The mean annual SCD exhibits an S-shape curve with elevation. Standard deviation of annual SCD forms a left-tailed bell-shape with the maximum at $5000 \mathrm{~m}$. The CV of annual SCD has a maximum of 0.85 at near $3000 \mathrm{~m}$, and then decreases to zero with increasing elevation.

Besides topographic factors (such as elevation, slope, and aspect), wind is also an important factor in alpine terrain that affects the accumulation and melting of snow. Wind-induced snow transport may lead to significant redistribution of the existing snow cover, where an increase of wind speed in the windward side of ridges increases erosion, while a decrease in wind speed in the leeward side of ridges increases 
deposition $[49,50]$. However, since there is a lack of wind data in the watershed, the effect of wind on snow cover redistribution was not examined in this research.

\section{Conclusions}

The Tizinafu watershed in the western Kunlun Mountains, a small but complex mountainous watershed with elevation ranging from 1500 to over $6000 \mathrm{~m}$, was chosen as the study area as little study has been done in the northern slope of the Himalaya Mountains. Because of the regional desert climate, snowmelt water is the primary water resource for the population in the downstream oases. Investigating the spatiotemporal characteristics of the snow cover using systematically collected remote sensing data is the first step in our efforts to understand and simulate the hydrological processes and to predict the future impacts of climate change for the watershed [19,51].

Daily snow cover data of 10 hydrological years (October 2002 to September 2012) in the watershed were created by first combining MODIS Terra (MOD10A1) and Aqua (MYD10A1) snow cover products and then employing a cloud-gap-filling temporal filter. The accuracy and cutoff of the temporal filter were assessed using a simulation approach, where the lowest mean absolute error of 3.5\% was found with a window size of nine days. Snow in the watershed generally starts melting in March and reaches the minimum in early August. Elevation is the primary control on snow cover. SCPs in five elevation bands increase consistently with the rise of elevation. Slope does not play a major role in snow distribution when it exceeds $10^{\circ}$, as there is a positive correlation between slope and elevation. The largest SCP difference is between the south-facing areas and the other aspects, and occurs between mid-October and mid-November with decreasing SCP, indicating that direct solar radiation may cause a reduction in snow cover.

There is a significant correlation between watershed SCP and annual total stream flow, indicating that snowmelt is a major source of stream runoff that might be predictable with SCP. In addition, the SCP of the middle elevation band (4200-4600 $\mathrm{m}$ ) has the strongest correlation with annual stream flow, while the SCPs in the lowest and highest elevation bands do not have significant correlation with stream flow. The investigation of future climate change, therefore, should focus on the temperature impact on the middle elevation band.

Future work will explore meteorological controls such as temperature, precipitation, and wind that influence the temporal and spatial distribution of snow cover in the watershed using remotely sensed meteorological data or data generated by climate models. We will further explore the possibilities of using remote sensing snow cover data in snowmelt runoff prediction and in the assessment of the impacts of climate change for the watershed.

\section{Acknowledgments}

This study is supported by the "One Hundred Talents Program" of the Chinese Academy of Sciences and is also in part supported by the National Natural Science Foundation of China (project \#41371365). 


\section{Author Contributions}

Yufang Zhang, Xingong Li, and Jiangfeng She are the principal authors of this manuscript. Yufang Zhang contributed at all phases of the investigation. All authors contributed equally in research design, selection of the methods, and interpretation of the results.

\section{Conflicts of Interest}

The authors declare no conflict of interest.

\section{References}

1. Viviroli, D.; Dürr, H.H.; Messerli, B.; Meybeck, M.; Weingartner, R. Mountains of the world, water towers for humanity: Typology, mapping, and global significance. Water Resour. Res. 2007, 43, doi: 10.1029/2006WR005653.

2. Brown, R.D. Northern Hemisphere snow cover variability and change, 1915-97. J. Climate 2000, 13, 2339-2355.

3. Dye, D.G. Variability and trends in the annual snow-cover cycle in Northern Hemisphere land areas, 1972-2000. Hydrol. Process. 2002, 16, 3065-3077.

4. Barnett, T.P.; Adam, J.C.; Lettenmaier, D.P. Potential impacts of a warming climate on water availability in snow-dominated regions. Nature 2005, 438, 303-309.

5. Déry, S.J.; Brown, R.D. Recent Northern Hemisphere snow cover extent trends and implications for the snow-albedo feedback. Geophys. Res. Lett. 2007, 34, DOI: 10.1029/2007GL031474.

6. Flanner, M.; Shell, K.; Barlage, M.; Perovich, D.; Tschudi, M. Radiative forcing and albedo feedback from the Northern Hemisphere cryosphere between 1979 and 2008. Nat. Geosci. 2011, 4, $151-155$.

7. Li, X.; Cheng, G.; Jin, H.; Kang, E.; Che, T.; Jin, R.; Wu, L.; Nan, Z.; Wang, J.; Shen, Y. Cryospheric change in China. Global Planet. Change 2008, 62, 210-218.

8. Che, T.; Xin, L.; Jin, R.; Armstrong, R.; Zhang, T. Snow depth derived from passive microwave remote-sensing data in China. Ann. Glaciol. 2008, 49, 145-154.

9. Wang, J.; Li, H.; Hao, X.; Huang, X.; Hou, J.; Che, T.; Dai, L.; Liang, T.; Huang, C.; Li, H. Remote sensing for snow hydrology in China: Challenges and perspectives. J. Appl. Remote Sens. 2014, 8, doi: 10.1117/1.JRS.8.084687.

10. Brown, R.; Derksen, C.; Wang, L. Assessment of spring snow cover duration variability over northern Canada from satellite datasets. Remote Sens. Environ. 2007, 111, 367-381.

11. Tong, J.; Déry, S.; Jackson, P. Topographic control of snow distribution in an alpine watershed of western Canada inferred from spatially-filtered MODIS snow products. Hydrol. Earth Syst. Sci. 2009, 13, 319-326.

12. Dahe, Q.; Shiyin, L.; Peiji, L. Snow cover distribution, variability, and response to climate change in Western China. J. Climate 2006, 19, 1820-1833.

13. Wang, X.; Xie, H. New methods for studying the spatiotemporal variation of snow cover based on combination products of MODIS Terra and Aqua. J. Hydrol. 2009, 371, 192-200. 
14. Pu, Z.; Xu, L.; Salomonson, V.V. MODIS/Terra observed seasonal variations of snow cover over the Tibetan Plateau. Geophys. Res. Lett. 2007, 34, L06706.

15. Liang, T.G.; Huang, X.D.; Wu, C.X.; Liu, X.Y.; Li, W.L.; Guo, Z.G.; Ren, J.Z. An application of MODIS data to snow cover monitoring in a pastoral area: A case study in Northern Xinjiang, China. Remote Sens. Environ. 2008, 112, 1514-1526.

16. Hall, D.K.; Foster, J.L.; DiGirolamo, N.E.; Riggs, G.A. Snow cover, snowmelt timing and stream power in the Wind River Range, Wyoming. Geomorphology 2012, 137, 87-93.

17. Dye, D.G.; Tucker, C.J. Seasonality and trends of snow-cover, vegetation index, and temperature in northern Eurasia. Geophys. Res. Lett. 2003, 30, 1405.

18. Bednorz, E. Snow cover in Eastern Europe in relation to temperature, precipitation and circulation. Int. J. Climatol. 2004, 24, 591-601.

19. Li, X.; Williams, M.W. Snowmelt runoff modelling in an arid mountain watershed, Tarim Basin, China. Hydrol. Process. 2008, 22, 3931-3940.

20. MODIS. Available online: Http://modis.gsfc.nasa.gov (accessed on 28 February 2015).

21. Hall, D.K.; Riggs, G.A.; Salomonson, V.V. Development of methods for mapping global snow cover using moderate resolution imaging spectroradiometer data. Remote Sens. Environ. 1995, 54, $127-140$.

22. Hall, D.K.; Riggs, G.A.; Salomonson, V.V.; Di Girolamo, N.E.; Bayr, K.J. MODIS snow-cover products. Remote Sens. Environ. 2002, 83, 181-194.

23. National Snow and Ice Data Center. Available online: Http://nsidc.Org (accessed on 28 February 2015).

24. Dwyer, M.J.; Schmidt, G. The MODIS reprojection tool. In Earth Science Satellite Remote Sensing; Springer: Berlin/Heidelberg, Germany, 2006; pp. 162-177.

25. Hall, D.; Riggs, G.; Salomonson, V. MODIS/Terra Snow Cover Daily L3 Global 500 m Grid V004, January to March 2003; Digital Media, Updated Daily; National Snow and Ice Data Center: Boulder, CO, USA, 2011.

26. Aster Global Digital Elevation Model. Available online: http://www.jspacesystems.or.jp/ersdac/ GDEM/E/4.html (accessed on 28 February 2015).

27. Hall, D.K.; Riggs, G.A. Accuracy assessment of the MODIS snow products. Hydrol. Process. 2007, $21,1534-1547$.

28. Bitner, D.; Carroll, T.; Cline, D.; Romanov, P. An assessment of the differences between three satellite snow cover mapping techniques. Hydrol. Process. 2002, 16, 3723-3733.

29. Klein, A.G.; Barnett, A.C. Validation of daily MODIS snow cover maps of the Upper Rio Grande River Basin for the 2000-2001 snow year. Remote Sens. Environ. 2003, 86, 162-176.

30. Zhou, X.; Xie, H.; Hendrickx, J.M. Statistical evaluation of remotely sensed snow-cover products with constraints from streamflow and SNOTEL measurements. Remote Sens. Environ. 2005, 94, 214-231.

31. Wang, X.; Xie, H.; Liang, T.; Huang, X. Comparison and validation of MODIS standard and new combination of Terra and Aqua snow cover products in northern Xinjiang, China. Hydrol. Process. 2009, 23, 419-429. 
32. Xie, H.; Liang, T.; Wang, X. Development and assessment of combined Terra and Aqua snow cover products in Colorado Plateau, USA and northern Xinjiang, China. J. Appl. Remote Sens. 2009, 3, 033559-033514.

33. Gao, Y.; Xie, H.; Yao, T.; Xue, C. Integrated assessment on multi-temporal and multi-sensor combinations for reducing cloud obscuration of MODIS snow cover products of the Pacific Northwest USA. Remote Sens. Environ. 2010, 114, 1662-1675.

34. Gao, Y.; Xie, H.; Lu, N.; Yao, T.; Liang, T. Toward advanced daily cloud-free snow cover and snow water equivalent products from Terra-Aqua MODIS and Aqua AMSR-E measurements. $J$. Hydrol. 2010, 385, 23-35.

35. Parajka, J.; Blöschl, G. Spatio-temporal combination of MODIS images-potential for snow cover mapping. Water Resour. Res. 2008, 44, doi: 10.1029/2007WR006204.

36. Gafurov, A.; Bárdossy, A. Cloud removal methodology from MODIS snow cover product. Hydrol. Earth Syst. Sci. 2009, 13, 1361-1373.

37. Parajka, J.; Pepe, M.; Rampini, A.; Rossi, S.; Blöschl, G. A regional snow-line method for estimating snow cover from MODIS during cloud cover. J. Hydrol. 2010, 381, 203-212.

38. Hall, D.K.; Riggs, G.A.; Foster, J.L.; Kumar, S.V. Development and evaluation of a cloud-gap-filled MODIS daily snow-cover product. Remote Sens. Environ. 2010, 114, 496-503.

39. Gao, Y.; Lu, N.; Yao, T. Evaluation of a cloud-gap-filled MODIS daily snow cover product over the Pacific Northwest USA. J. Hydrol. 2011, 404, 157-165.

40. Dozier, J.; Painter, T.H.; Rittger, K.; Frew, J.E. Time-space continuity of daily maps of fractional snow cover and albedo from MODIS. Adv. Water Resour. 2008, 31, 1515-1526.

41. Rittger, K.; Painter, T.H.; Dozier, J. Assessment of methods for mapping snow cover from MODIS. Adv. Water Resour. 2013, 51, 367-380.

42. Zheng, D.; Zhang, B. A study on the altitudinal belts and environmental problems of the Karakoram and West Kunlun Mountains. J. Nat. Resour. 1989, 4, 254-266.

43. Cazorzi, F.; Dalla Fontana, G. Snowmelt modelling by combining air temperature and a distributed radiation index. J. Hydrol. 1996, 181, 169-187.

44. Hock, R. A distributed temperature-index ice-and snowmelt model including potential direct solar radiation. J. Glaciol. 1999, 45, 101-111.

45. Whetton, P.; Haylock, M.; Galloway, R. Climate change and snow-cover duration in the Australian Alps. Clim. Change 1996, 32, 447-479.

46. Hantel, M.; Ehrendorfer, M.; Haslinger, A. Climate sensitivity of snow cover duration in Austria. Int. J. Climatol. 2000, 20, 615-640.

47. Dietz, A.J.; Conrad, C.; Kuenzer, C.; Gesell, G.; Dech, S. Identifying changing snow cover characteristics in Central Asia between 1986 and 2014 from remote sensing data. Remote Sens. 2014, 6, 12752-12775.

48. Sun, C.; Li, X.; Chen, Y.; Shen, B.; Li, W. Climate change and stream flow response of a mountain river in Western Kunlun Mountains. Clim. Change 2015, under review.

49. Mott, R.; Schirmer, M.; Bavay, M.; Grünewald, T.; Lehning, M. Understanding snow-transport processes shaping the mountain snow-cover. The Cryosphere 2010, 4, 545-559.

50. Dadic, R.; Mott, R.; Lehning, M.; Burlando, P. Wind influence on snow depth distribution and accumulation over glaciers. J. Geophys. Res. 2010, 115, F01012. 
51. She, J.; Zhang, Y.; Li, X.; Chen, Y. Changes in snow and glacier cover in an arid watershed of the western Kunlun Mountains using multisource remote-sensing data. Int. J. Remote Sens. 2014, 35, 234-252.

(C) 2015 by the authors; licensee MDPI, Basel, Switzerland. This article is an open access article distributed under the terms and conditions of the Creative Commons Attribution license (http://creativecommons.org/licenses/by/4.0/). 